\title{
Legal Certainty Due to Marriage Agreement in Mixed Marriage
}

\author{
Ni Luh Putu Okky Ratna Dewi \\ Magister of Notary in the Faculty of Law, University of Mataram, Indonesia
}

\begin{abstract}
The purpose of this study was to determine and analyze the legal certainty of a marriage agreement deed for the parties in mixed marriages and to find out and analyze the legal protection of those who entered into a marriage agreement in mixed marriages. The type of research used is normative legal research, with the statutory approach and the conceptual approach. The legal certainty of a marriage agreement for the parties in a mixed marriage of citizens made by a notary in Indonesia, has strong legal power in Indonesia and can be used as written evidence if later there are legal problems between the husband and wife who make a marriage agreement. Under the Indonesian legal system, the marriage agreement deed made by a Notary Public has the power of proof of a perfect law. Marriage agreements are included in the category of preventive legal protection. The marriage agreement can take effect at the time the marriage takes place, the time provisions on this matter must be interpreted when the marriage has been recorded. By recording the marriage will have authentic evidence that guarantees legal certainty, namely the marriage certificate. Marriage agreements objectively provide legal protection for those who have more assets in the marriage and can minimize disputes when the marriage is broken.
\end{abstract}

Keywords: legal certainty, marriage agreements, mixed marriages

DOI: $10.7176 / J L P G / 92-27$

Publication date: December $31^{\text {st }} 2019$

\section{INTRODUCTION}

Every human being has the basic right to continue his descendants through marriage. Indonesia as a multicultural state of law upholds the implementation of Human Rights (HAM), this can be seen in article 28B of the 1945 Constitution of the Republic of Indonesia (URI NRI 1945). Although there are differences in terms of implementation caused by cultural diversity as well as the culture and religion adopted by the parties.

Marriage is one of the fields of civil law that has sensitive nature and the potential to cause conflict, one of which relates to joint property in mixed marriages. Law Number 1 of 1974 concerning Marriage (Marriage Law) provides the meaning of mixed marriages in Article 57 "is a marriage between two people who in Indonesia are subject to different laws, due to differences in citizenship and one of the parties of Indonesian citizenship."

Foreigners have the right to marry and can choose Indonesian as their partner. Then with that marriage foreigners have the right to obtain Indonesian citizens (Supramono, 2012). However, problems will arise when the foreigner marries a citizen without changing citizenship.

Mixed marriages in certain cases still apply the legal rules of the State party of the citizen, as well as the law of the foreigner, so there is legal uncertainty. It is different if both parties agree to choose one nationality (both foreigners and citizens) so that there will be no legal chaos resulting from the application of two different legal systems, because there will only be one legal system that regulates them.

Mixed marriages and marriages conducted outside Indonesia involve 2 (two) different legal systems, so that the procedures and provisions that affect the validity of the marriage and the legal consequences need to pay attention to the legal system of each party.

There are main problems in mixed marriages, namely: First, the law applies when foreigners do marriages with Indonesian citizens without changing citizenship, because mixed marriages in certain cases still apply the rules of each party, so there is legal uncertainty regarding shared property. Mixed marriages and marriages conducted outside Indonesia involve 2 (two) different legal systems, so that the procedures and provisions that affect the validity of the marriage and the legal consequences need to pay attention to the legal system of each party. Second, the legal protection of the parties in the marriage agreement is made by a notary, given the legal uncertainty.

Based on these main problems, the focus of this study is to analyze the legal certainty of the marriage agreement deed for the parties in mixed marriages and analyze the legal protection of the parties who entered into marriage agreements in mixed marriages.

\section{METHODOLOGY}


This research uses normative legal research. In this study, law is conceptualized as what is written in the legislation (law in books) or law is conceptualized as a rule or norm that is a benchmark of human behavior that is considered appropriate (Marzuki, 2005: 33; Amirudin and Asikin, 2012: 118).

The approach method used is the statutory approach and the conceptual approach (Marzuki, 2005: 93).

Types and sources of legal materials needed are primary legal materials, secondary legal materials, and tertiary legal materials. Primary Legal Material, namely: Civil Code, Marriage Law, Government Regulation Number 9 of 1975 concerning the Implementation of Marriage Law. Secondary Legal Material, namely legal material obtained from documents, books, research results or legal scientific research reports relating to research topics, views / opinions (doctrines), legal scientific journals. Tertiary legal materials, namely those that provide guidance or explanations for primary and secondary legal materials.

The technique of collecting legal materials is done by collecting all legal materials that are relevant to the problem under study through the study of documents with stages of inventory, systematization, synchronization, and harmonization of various related legal documents.

\section{DISCUSSION}

\section{Legal Certainty Deed of Marriage Agreement for Parties in Mixed Marriage}

a) Arrangement of Marriage Agreement in Indonesia

Regulations governing marital agreements in Indonesia are regulated in the Civil Code and Law Number 1 of 1974 concerning Marriage (Marriage Law).

The Civil Code does not provide an understanding of marriage. As is known the Civil Code views marriage only as a civil relationship. This means that a marriage is considered valid if the marriage conditions as determined by the law are fulfilled. The Civil Code does not consider the importance of religious elements in marriage.

The concept of marriage according to the Civil Code is different from the concept of marriage according to the Marriage Law. Based on the definition of marriage in Article 1 of the Marriage Law, marriage is not only understood from the juridical element but also from biological, sociological, and religious elements.

Divorce results in legal consequences for divorced husband and wife, children, and property. With regard to husband and wife, divorce results in the elimination of all the consequences of marriage such as the rights and obligations of husband and wife during marriage. The wife regained her position as an unmarried woman. Parental power is also stopped by the existence of divorce, because it changes with guardianship. Guardianship of minors is determined by the Court. Togetherness of property in marriage also stops with divorce. Joint assets in a marriage are divided as assets between husband and wife.

Article 119 of the Civil Code states that "from the time the marriage takes place, for the sake of law a unified union between husband and wife assets shall be held, only concerning this with the marriage agreement no other provisions are held". Different from the marriage agreement in the Marriage Act in Chapter V Article 29, it states that:

1. "At the time or before the marriage takes place both parties with mutual agreement can enter into a written agreement ratified by the Registrar of Marriage, after which the contents also apply to third parties, as long as the third party is involved

2. The agreement cannot be ratified if it violates the legal, religious and moral boundaries

3. The agreement is valid since the marriage is held

4. During the marriage the agreement cannot be changed, except if from both parties there is agreement to amend and the change does not harm a third party. "

Subekti (1994: 4) states that a marriage agreement is an agreement concerning the property of a husband and wife, as long as their marriage deviates from the principle or pattern established by law.

Prawirohamidjojo (1994: 57), views the marriage agreement as an agreement made by the prospective husband and wife before or at the time of marriage to regulate the effect of marriage on their assets.

Thus, a marriage agreement only regulates the assets of a husband and wife in a marriage, wherein in the marriage agreement the prospective husband or prospective wife can declare their will on the marriage property, whether they will agree to unite their assets or they conduct the pooling of assets only limited or they decide not to unite their assets at all in the marriage they are having.

An agreement is said to be valid if the agreement has fulfilled the legal requirements of an agreement, namely an agreement, skills, certain things, and a lawful cause as determined in Article 1320 of the Civil Code. In the Civil Code, the marriage agreement is generally determined in Article 139 through Article 154. In Article 139 the Civil Code says that by entering into a marriage agreement, the two candidates for 
husband and wife are entitled to prepare some deviations from the legislation surrounding the union of assets, provided that the agreement is not violates the good moral or public order and as long as all the provisions below are heeded according to the next article.

The Civil Code regulates marital agreements in several provisions, namely Article 141, Article 147, and Article 149. A marriage agreement is an agreement that regulates marital assets. Provisions governing marital agreements in the Civil Code are contained in the First Book About People. In addition to the general requirements regarding the validity of an agreement, in making a marriage agreement, a prospective husband and wife must also pay attention to special requirements regarding the marriage agreement that must be fulfilled.

Based on the provisions of Article 141, Article 147 and Article 149, marriage agreements do not include divorce. The contents of a marriage agreement can be about everything, as long as it does not violate the law, religion, and decency. Marriage agreements are also not only to do the separation of property, but can also unite the property, depending on what is agreed upon by the parties. The existence of this marriage agreement does not eliminate the husband's obligation to continue to meet household needs (Damanhuri, 2012: 12).

Differences in the concept of assets in a marriage according to the Civil Code and the Marriage Law, make the concept of a marriage agreement based on the two laws are also different. Article 119 of the Civil Code states that "from the time the marriage takes place, for the sake of law a unified union between husband and wife assets shall be held, only concerning this with the marriage agreement no other provisions are held".

Based on these provisions, it can be understood that the Civil Code considers marriage agreements generally made to deviate the regulatory system stipulated in the article, namely the mixing of assets in a marriage. All assets obtained in a marriage, both obtained by the husband and wife, automatically according to the law become jointly owned assets. The marriage agreement was made with the intention, among other things, as an exception to the mixing of these assets.

Article 119 has clearly stated that according to the Civil Code in a marriage a unity of assets will automatically occur immediately after the marriage takes place if not otherwise stipulated, which then in Article 139 stipulates that if there are irregularities then the deviations are made in the marriage agreement. Thus, theoretically the concept of a marriage agreement according to the Civil Code is to separate property. In the Marriage Law, the united assets are only assets obtained during the marriage. While the inherited assets obtained by each party remain under the control of each party and do not enter into joint property.

The concept of a marriage agreement in the Marriage Law can be understood from the concept of assets in a marriage that is explained in Article 35 paragraph (2). Article 35 paragraph (2) which states that "the inheritance of each husband and wife and property obtained as a gift and inheritance respectively, is under the control of each other as long as the parties do not determine otherwise". From this, the concept of a marriage agreement regarding assets based on the Marriage Law is theoretically to unite property, because the inherited property under the control of each party can be promised in a marriage agreement to enter into joint property.

Related to the expansion of the contents of the marriage agreement, the marriage law basically does not regulate the contents of the marriage agreement. In contrast to the Civil Code, the contents of a marriage agreement have been determined, for example regarding the unity of profit and loss, about the union of results and income, or about the wife's right to take a sum of money from assets for household needs.

After the marriage takes place, the Marriage Law only provides an opportunity to change the marriage agreement with certain conditions, as in Article 29 paragraph (4) of the Marriage Law.

The timing of making a marriage agreement based on the Marriage Act raises a vague meaning. Provisions for making marriages "when" marriages take place are very unclear. Marriage Law is a unification of the national marriage law, so the Marriage Law is universal for all Indonesian citizens, but the Marriage Law is also deferential, because the legality of marriage is based on the law of each religion adhered (Djubaidah, 2012: 213), while the religion in Indonesia there are various kinds and the conditions for the implementation of marriage are also various.

Decision of the Constitutional Court Number 69 / PUU / XIII / 2015 related to Article 29 of Law Number 1 of 1974 concerning Marriage has provided a constitutional interpretation so that it changes the formulation of Article 29 of the Marriage Law of 1974, particularly regarding the making of marriage agreements.

Implications of the Constitutional Court Decision Number 69 / PUU / XIII / 2015 for Article 29 of the Marriage Law of 1974 indicates that there is legal uncertainty and does not provide legal protection.

The issuance of the Constitutional Court Decision Number 69 / PUU / XIII / 2015, especially towards the application of Article 29 of the Marriage Law. The Constitutional Court broadens the meaning of marriage 
agreement making in accordance with the legal needs of each partner. In its ruling, the Constitutional Court stated that Article 29 paragraph (1) of the Marriage Law was declared unconstitutional conditional as long as it was not interpreted "At the time, before it was held or during marriage, both parties with mutual agreement could submit a written agreement that was ratified by the marriage registrar or notary public, which also applies to third parties as long as the third party is involved ".

Article 29 paragraph (3) of the Marriage Law is declared to be unconstitutional conditional as long as it is not interpreted "The agreement shall take effect since the marriage takes place, unless otherwise stipulated in the Marriage Agreement". Meanwhile, Article 29 paragraph (4) of the Constitutional Unconstitutional Marriage Act as long as it is not interpreted, marriage agreements can be regarding marriage assets or other agreements, cannot be changed or revoked, except if from both parties there is an agreement to change or revoke, and the change or revocation does not harm third parties".

In connection with this, the marriage agreement before the Constitutional Court Decision, namely the making of a marriage agreement can be made as long as the marriage contract takes place by a notary without having to be preceded by the establishment of an authorized court. The phenomenon that occurs in the community is found marriage agreements made at the time of the marriage took place for certain reasons between the husband and wife. So that the legal consequences of making a marriage agreement after marriage before the Constitutional Court Ruling is a change in the status of husband and wife property and binding on both parties and against third parties. The marriage agreement after the Constitutional Court's Decision, which determines that the provisions in Article 29 paragraph (1), paragraph (3), and paragraph (4) are unconstitutional conditionally with the 1945 Constitution as stated in its decision.

Based on the decision of the Constitutional Court, it has made changes in the Marriage Law, especially in the case of the marriage agreement, so that the contents of Article 29 of the Marriage Law in terms of the marriage agreement become:

1. At the time, before it takes place or during marriage, both parties with mutual agreement can submit a written agreement that is ratified by the marriage registrar or notary, after which the contents also apply to third parties as long as the third party is involved;

2. The agreement cannot be ratified if it violates the limits of law, religion and decency;

3. The agreement is valid since the marriage takes place unless specified otherwise in the marriage agreement;

4. During the marriage, the marriage agreement can be regarding marriage assets or other agreements, can not be changed or revoked, unless both parties have an agreement to change or revoke, and the change or revocation does not harm a third party.

\section{b) Mixed Marriage in the Indonesian Legal System}

Mixed marriages based on Article 57 of the Marriage Law are marriages between two people who are subject to different laws in Indonesia because of differences in citizenship and one of the parties is Indonesian citizenship. Article 58 of the Marriage Law then states that for persons of different nationalities who engage in mixed marriages can obtain citizenship from their husband or wife and may also lose citizenship, according to the methods determined in the applicable citizenship law of the Republic of Indonesia.

Article 57 only limits the meaning of mixed marriages to marriages between an Indonesian citizen and a non-Indonesian citizen. Further provisions regarding mixed marriages are contained in Article 59 to Article 62 of the Marriage Law. So the mixed marriage described in the Marriage Law is a marriage because of differences in citizenship or differing understanding of the law, not a mixture caused by religious differences. Concerning mixed marriages is contained in Part Three namely Article 57 to Article 62 of the current Marriage Law. Whereas marriages outside Indonesia are regulated in Article 56 of the Marriage Law.

\section{c) Marriage Agreement in Mixed Marriage}

An example of a mixed marriage agreement is an agreement made by Notary I Nengah Sukma Mulyawan, with the parties namely Sri Nurlaela as an Indonesian citizen, and Michael Wuhrer as a Dutch citizen. The contents of the marriage agreement are as follows.

Table 1. The substance of the WNI Mixed Marriage Agreement with the foreigners

\begin{tabular}{lll}
\hline NO. & Aspects & Description \\
\hline 1 & Division of property & Article 1 \\
\hline
\end{tabular}


During the Marriage Period, the parties agree that:

a. Property acquired during marriage becomes joint property, including property obtained by the parties because of luck or chance;

b. The inheritance of each party and the property obtained by each party as a gift and / or inheritance, is under the control of each party as long as the parties do not specify otherwise.

Article 2

- Regarding joint property, the parties can act on the agreement of both parties

- Regarding their respective belongings, each party has the full right to take legal actions regarding his property.

$2 \quad$ Household Costs

3

Marriage

Breakup/Divorce

4 Dispute resolution

\section{Article 3}

- All expenses incurred for the household and maintenance and education of children born from their marriages are borne and must be borne and paid by the husband and wife - together.

- Whereas ordinary and daily expenses for household needs carried out by the wife, are considered to have been carried out with the husband's approval.

\section{Article 5}

If the marriage is terminated due to divorce, the joint property will be divided fairly and fairly and / or regulated according to their respective laws.

\section{Article 6}

- If the marriage is breakup because one of the parties dies, then the property which is jointly owned (Harta Bersama) falls on the party that lives longer without any calculation.

- Furthermore, both now and in the future those who live longer will not get any form of demand either from the heirs of the parties or from other parties who claim to have rights first or to have rights to it.

\section{Article 8}

- If there are differences of opinion or disputes between the parties in this deed regarding the implementation of the Marriage Agreement Regarding Joint Assets referred to in this deed, the parties hereby choose the procedure of dispute resolution or dissent through the Settlement Procedure outside the Court, by means of deliberations to reach consensus, among others by means of consultation, negotiation, mediation, conciliation or expert judgment, in accordance with applicable laws and regulations concerning Alternative Dispute Resolution.

- Regarding Alternative Dispute Resolution referred to in this deed, the parties hereby have selected a special and permanent place of settlement (forum) at the lawyer's office chosen by the parties.

- Regarding this deed with all legal consequences and its implementation, the parties hereby choose a public and unchanging domicile at the Registrar's Office of the Mataram District Court in the City of Mataram.

\section{d) Legal Certainty Deed of Agreement in Mixed Marriage}

Based on the description above, there are two important things regarding marriage agreements. First, this agreement is not a necessity in regulating property, because based on the provisions of Article 119 of the Civil Code, starting when the marriage takes place, by law a united union between the wealth of husband and wife's assets is enforced. Even without a marriage agreement, a marriage can still be carried out. In other words, a marriage agreement is only an institution that is prepared if there are parties who feel the 
need to make an agreement to avoid disputes behind the day, for example regarding the separation between personal property and joint property. Second, related to the contents of the agreement although it was basically released but could not be ratified if it violated the limits of law, religion, and morality.

The concept of a marriage agreement as described earlier is the basic concept of a marriage agreement that involves matters concerning property. Related to the expansion of the contents of the marriage agreement, the Marriage Law basically does not regulate the contents of the marriage agreement. In contrast to the Civil Code, the contents of a marriage agreement have already been determined.

In its development the marriage agreement developed. Separation of assets is not the only reason marriage agreements are made. The contents of the marriage agreement are not limited to economic problems. However, in general marriage agreements are made by prospective husbands and future wives to regulate the legal consequences in their marriages. According to Mulyadi (2008: 41), "a legal marriage will have legal consequences, namely: (1) The emergence of a relationship between husband and wife; (2) The emergence of property in marriage; and (3) The emergence of relationships between parents and children ". In addition to assets in a marriage, a marriage agreement can also contain matters that are feared to cause problems during the marriage, as well as if there is a marriage breakup. For example: about monogamy, about the personal right to choose a family name, about the rights and obligations of a husband and wife in marriage, about the work of each husband and wife, about parties who are not allowed to do violence in the household, about their responsibilities each of the children born into a marriage. In other words, husband and wife have a free but limited agreement to determine the contents of the marriage agreement.

Under the Indonesian legal system, the position of the agreement before marriage is stronger than the existing regulations in the Marriage Law. Because the agreement can protect the rights of both parties. If there is a divorce and a dispute between the two, then the marriage agreement made by a Notary in Indonesia can be used as a guide for settlement.

\section{Legal Protection of the Parties Who Made Marriage Agreements in Mixed Marriage}

Preventively, the Government has provided protection efforts to married couples to prevent disputes in marital property by opening up opportunities to determine other laws for husband and wife regarding marital property, namely by making marriage agreements made by husband and wife before or during the marriage.

In the Marriage Law, no detailed explanation is found about the form of shared assets and luggage. The Marriage Law only states that joint assets are assets obtained during a marriage. Regarding property, there is not enough explanation regarding the intended property, both the forms and the information of the time when an asset is classified as an asset, and also regarding the provision of shared assets in the event of a divorce. It is not explained in detail.

Article 37 only emphasizes that if a marriage is terminated due to divorce, joint property is regulated according to their respective laws. The Marriage Act also does not regulate the resolution of the problem of inherited property of a husband or wife who enters into a marriage which is then mixed with shared property. These articles which have unclear provisions, will bring multiple interpretations to the application of law in the field.

If there is a dispute over marital property, the unclear law is handed over to the judge by interpreting the law based on a sense of legal justice from the judge concerned. The judge is obliged to seek his own law for a case with unclear rules. Although it is not possible that the law can provide full protection of the interests of one, and ignore the interests of others because of the full protection of the interests of one person, means ignoring the interests of others in part or in full.

Sumiarni (2004: 10) argues that "the registration of marriage is an authentic certificate as authentic evidence of marriage as well as birth certificates and death certificates". Therefore, related to differences of opinion regarding the validity of this marriage, a marriage agreement can provide legal protection when a marriage has been registered. Even though the marriage has been declared legally religious, the marriage certificate obtained by recording the marriage is authentic evidence that guarantees legal certainty for husband and wife.

The obscurity of the rules regarding the legality of marriage is the basis for the wife to deny the validity of the marriage agreement. By making a marriage agreement, the husband's rights are protected from the wife's bad intentions. Under these conditions the marriage agreement can be a means of providing legal protection for parties to the marriage from the ill will of the other party. Although in this case it is clear that the marriage agreement objectively provides protection for those who have more wealth. 
For mixed couples between Indonesian citizens and foreigners, the marriage agreement provides protection, because the Indonesian state is adhering to a single citizenship. Indonesian law states that a citizen who is married to a foreigner even though he / she has not moved citizenship / is still a citizen but is considered to have lost his Indonesian citizenship and is equal to a foreigner. Thus, to own land and property in Indonesia, the status cannot be owned (Basic Agrarian Law 1960). This is based on the Basic Agrarian Law Article 21 Paragraph (3) which states that: Foreigners who after the enactment of this Law obtain property rights due to inheritance without a will or mixing of assets due to marriage, as well as Indonesian citizens who have rights property and after the entry into force of this Law loses its citizenship shall waive that right within one year from the acquisition of that right or the loss of citizenship. If after that period the title is released, the right is void because the law and land fall on the State, provided that the rights of the other party that encumber him continue.

As a follow-up to the development and protection of foreign nationals in Indonesia, on December 22, 2015, Government Regulation (PP) Number 103 of 2015 concerning Housing Ownership by Residents residing in Indonesia was born. The regulation states that: "Foreigners can own a home for residence or residence with Usage Rights,"

M. Rezfah Omar said that "the position of the agreement before marriage is stronger than the regulations in the Marriage Law. Because the agreement can protect the rights of both parties. If there is a divorce and a dispute between the two, then the prenuptial agreement can be used as a guide for settlement. In fact, what is regulated by the Marriage Law can be canceled by the prenuptial agreement "(Roring, 2104: 24).

M. Rezfah Omar's opinion is very relevant if it is related to Article 1338 paragraph (1) which states that "an agreement made legally, applies as a law for those who make it".

A marriage agreement is made with the aim of providing legal protection for parties in good faith from other parties in bad faith. If at other times problems arise between the parties, the marriage agreement can become the basis for each party, namely husband and wife, to implement and provide boundaries of rights and obligations between them.

In accordance with Gustav Radbruch's theory of legal objectives, the marriage agreement must have value for the parties to the marriage. Aside from being a legal protection for the parties, the marriage agreement also provides benefits in the event of a conflict in the court institution when a divorce occurs. As it is generally known that, dispute resolution through court takes a relatively long time and also requires a lot of money.

Basically, making a marriage agreement can provide legal protection for the parties who made it. For a mixed pair of Indonesian citizens with foreign citizens to help own land and property in Indonesia, the status cannot be owned. The marriage agreement is actually protecting both parties after the marriage is carried out, so that those who carry out the agreement are not easy to commit violations.

In addition, if at any time a conflict arises between the parties that have entered into such mixed marriages, the marriage agreement that has been made before the marriage takes place can be used as a reference and basis for each party in carrying out the obligations, and providing boundaries of rights and obligations between them. Secondly, the Deed of agreement made at a Notary Public can be used as written evidence if a legal problem occurs between the husband and wife who make a marriage agreement before a Notary. Because the Notary Deed has perfect proof power as Article 1868 of the Civil Code and Notary authority in Article 15 of the UUJN, the notary deed is categorized as an Authentic Deed.

Legal protection in a marriage agreement indeed tends to regulate property, so the essence is aimed at those who have more assets. However, those who have less or no assets can still use the marriage agreement as a means of legal protection. As explained earlier, the contents of a marriage agreement can be expanded not only to regulate property, but also to regulate other things that are possible in the domestic life.

An ideal marriage agreement is a marriage agreement that can protect and provide justice for parties in a marriage. According to Aburaera (2013: 179), a sense of justice sometimes lives outside the law, so the law will be difficult to compensate for that sense of justice. As a result, the law itself will be felt unfair.

\section{CONCLUSION}

Legal certainty of a marriage agreement for the parties in a mixed marriage of a citizen made by a notary in Indonesia has strong legal force in Indonesia and can be used as written evidence, if later there are legal problems between the husband and wife who make a marriage agreement. Under the Indonesian legal system, the marriage agreement deed made by a Notary Public has the power of proof of a perfect law. In the event of a dispute, if the husband / wife's state does not recognize the existence of a marriage agreement, the marriage agreement made by the notary can be taken into account in determining the distribution of 
property between the parties in the case of divorce, and under certain circumstances it will be taken into consideration by the court.

Marriage agreements are included in the category of preventive legal protection. Marriage agreements can come into force when the marriage takes place and act as authentic evidence. Objectively provide legal protection for those who have more wealth in the marriage. For those who are economically weak, marriage agreements can be used as a means of legal protection by extending the contents of the marriage agreement. Marriage agreements can minimize disputes when marriages break up. Marriage agreements that have been made before the marriage can be used as a reference in carrying out obligations in a conflict, and provide limits on the rights and obligations of the parties.

\section{REFERENCES}

Book

Damanhuri, H. R. (2007). Segi-Segi Hukum Perjanjian Perkawinan Harta Bersama. Bandung: Mandar Maju.

Amiruddin dan Asikin, Z. (2012). Pengantar Metode Penelitian Hukum. Cet. VI. Jakarta: Rajawali Pers.

Butarbutar, E. N. (2012). Hukum harta kekayaan menurut sistematika KUH Perdata \& perkembangannya. Bandung: Refika Aditama.

Sumiarni, M. E., \& Tangkilisan, H. N. S. (2004). Kedudukan suami isteri dalam hukum perkawinan: kajian kesetaraan jender melalui perjanjian kawin. Yogyakarta: Wonderful Publishing.

Roring, F. V. C. (2014). Perlindungan hukum terhadap harta dalam perjanjian perkawinan. Lex privatum, 2(3).

Supramono, G. (2012). Hukum orang asing di Indonesia. Jakarta: Sinar Grafika.

Mulyadi (2008). Hukum Perkawinan Indonesia. Semarang: Badan Penerbit Universitas Diponegoro.

Djubaidah, N. (2012). Perkawinan Tidak Dicatat menurut Hukum Tertulis di Indonesia dan Hukum Islam, cet. 2. Jakarta: Sinar Grafika.

Marzuki, P. M. (2005). Penelitian Hukum, Cet.ke-1. Jakarta: Kencana Prenada Media Group.

Subekti, R. (1994). Pokok-Pokok Hukum Perdata. Jakarta: Intermasa.

Aburaera, S. (2013). Filsafat Hukum. Jakarta: Kencana Prenada Media.

Prawirohamidjojo, S. (1994). Pluralisme dalam Perundang-undangan Perkawinan di Indonesia. Surabaya: Airlangga Press.

\section{Journal Article/Thesis/ Dissertation}

Supriyanto, A. (2008). Pengurusan dan Pertanggungjawaban Terhadap Harta Kekayaan Akibat Adanya Perjanjian Perkawinan (Doctoral dissertation, program Pascasarjana Universitas Diponegoro).

Liongan, C. (2007). Penyelesaian Pembagian Harta Perkawinan Bagi Wni Keturunan Tionghoa, Setelah Berlakunya Undang-Undang Nomor 1 Tahun 1974 Tentang Perkawinan Di Kota Manado, Sulawesi Utara (Doctoral dissertation, Program Pascasarjana Universitas Diponegoro).

Dampu, D. (2009). Pelaksanaan Perkawinan Antar Warga Negara Indonesia Dan Warga Negara Asing Setelah Berlakunya Undang-Undang Nomor 1 Tahun 1974 Tentang Perkawinan Di Kota Denpasar Provinsi Bali (Execution of Marriages Between Indonesian Citizens and Foreign Citizenz After the Legalization of Act Number 1 Year 1974 Concerning Marriage in Denpasar City Bali Province) (Doctoral dissertation, program Pascasarjana Universitas Diponegoro).

Mulyati, D. (2017). Pelaksanaan Perjanjian Pemisahan Harta Dalam Perkawinan Warga Negara Indonesia Dengan Warga Negara Asing. Jurnal IUS Kajian Hukum dan Keadilan, 5(2), 263-282.

Pujirahayu, E. W. (1991). Implementasi Kebijaksanaan Pemerintah Melalui Peraturan PerundangUndangan dalam Perspektif Sosiologis. (Disertasi Program Pascasarjana Universitas Airlangga).

Widanarti, H. (2018). Akibat Hukum Perkawinan Campuran Terhadap Harta Perkawinan (Penetapan Pengadilan Negeri Denpasar No: 536/Pdt. P/2015/PN. Dps.). Diponegoro Private Law Review, 2(1). p. 162.

Rasjid, I. (2013). Tinjauan Perjanjian Perkawinan Terhadap Perkawinan Campuran Warga Negara Indonesia - Warga Negara Australia Yang Dilangsungkan Di New South Wales - Australia. (Tesis, Fakultas Hukum, Magister Kenotariatan, Universitas Indonesia).

Peraturan Perundang-Undangan

Undang-Undang Dasar Negara Republik Indonesia Tahun 1945 (URI NRI 1945). 
Burgerlijk Wetboek (An: Kitab Undang-Undang Hukum Perdata), diterjemahkan oleh R. Subekti dan R. Tjitrosudibio, Cet.Ke-35, 2004, Pradnya Paramita, Jakarta.

Undang-Undang Nomor 1 Tahun 1974 tentang Perkawinan, Lembaran Negara tahun 1974 No. 1, Tambahan Lembaran Negara No.27

Undang-Undang Nomor 16 Tahun 2019 tentang Perubahan Atas Undang-Undang Nomor 1 Tahun 1974 tentang Perkawinan 